\title{
Evaluation of the Effect of Less Negatively Charged Amino Acid Substitution in Synthetic Tetramer Peptide S3 Derived from Horseshoe Crab Ambocyte on its Antibacterial Properties
}

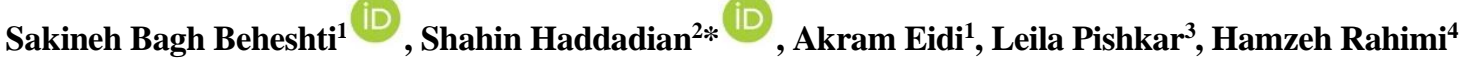 \\ ${ }^{1}$ Dept of Biology, Islamic Azad University, Science and Research Branch, Tehran, Iran \\ ${ }^{2}$ Dept of Nanotechnology, Dept of New Technologies Research, Pasteur Institute of Iran, Tehran, Iran \\ ${ }^{3}$ Dept of Biology, Faculty of Sciences, Islamic Azad University, Islamshahr Branch, Islamshahr, Iran \\ ${ }^{4}$ Dept of Molecular Medicine, New Technologies Research Group, Pasteur Institute of Iran, Tehran, Iran
}

Article Info

Article type:

Research article

\section{Article History:}

Received: 10 April 2021

Revised: 08 May 2021

Accepted: 29 June 2021

\section{* Correspondence to: \\ Shahin Haddadian \\ Dept of Nanotechnology, Dept of \\ New Technologies Research, \\ Pasteur Institute of Iran, Tehran, \\ Iran \\ Email: hadadian@yahoo.com}

\section{A B S T R A C T}

Introduction: The study of the effects of synthetic peptides with antibacterial properties can provide more effective antibiotics. This study designed, expressed, and investigated the Sushi 3 tetramer peptide. Subsequently, it was compared in terms of changing antibacterial properties with another Sushi3 tetramer peptide the aspartic acid and proline amino acids of which were replaced with glycine and serine amino acids.

Material \& Methods: First, the mentioned Sushi3 tetramer peptide sequences were designed, constructed, and named Mer1 and Mer 2, respectively, and cloned separately into plasmid pET-26b (+) and finally transferred to E.coli BL21 host (DE3). After the expression of the peptides, the presence of peptides was confirmed by SDS-PAGE and Western blotting. Afterward, the antimicrobial activity of Mer1 and Mer 2 was evaluated and compared. Finally, the toxicity of the two tetramers made on the MDA-MB-231 cell line was evaluated and compared.

Findings: Mer1 and Mer 2 had similar protein expression, and the toxic effect of both peptides on the cell line was not significantly different. however, Mer 2 had more effective antimicrobial effects than Mer1 at the same concentrations.

Discussion \& Conclusion: Evaluation of the effect of amino acid replacement with less negatively charge on increasing the antimicrobial activity of peptides is a suitable strategy. The above results increase the possibility of designing and producing antimicrobial peptides against antibiotic-resistant strains as the next generation of antibiotics.

Keywords: Antimicrobial peptides, Factor c, Horseshoe crab, Sushi3 tetramer peptide

$>$ How to cite this paper

Bagh Beheshti S, Haddadian Sh, Eidi A, Pishkar L, Rahimi H. Evaluation of the Effect of Less Negatively Charged Amino Acid Substitution in Synthetic Tetramer Peptide S3 Derived from Horseshoe Crab Ambocyte on its Antibacterial Properties. Journal of Ilam University of Medical Sciences. November 2021;29(4): 103-116. 


\section{ارزيابى تأثير جايكزينى اسيد آمينه هايى با بار منفى كمتر در يتيد تترامر سنتيك S3 مشتق از

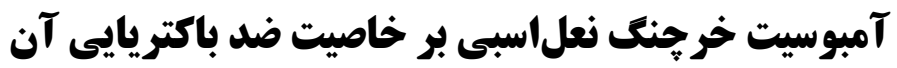

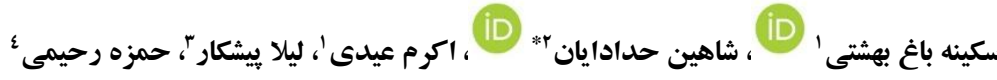
' خروه زيستشناسى، دانشكاه آزاد اسلامى، واحد علوم و تحقيقات، تهران، ايران

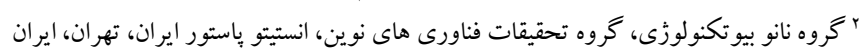

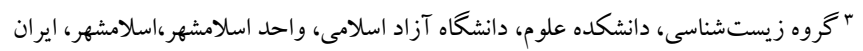

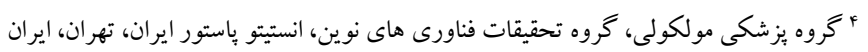

مقدمه: بررسى آثار ييتيدهاى داراى خاصيت ضدباكتريايى مى تواند راه را براى بهدست آوردن آنتىبيوتيككهاى مؤثرتر نوع مقاله: يُزوهشى

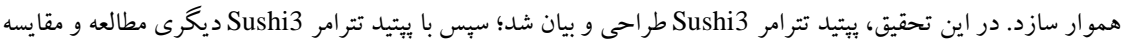

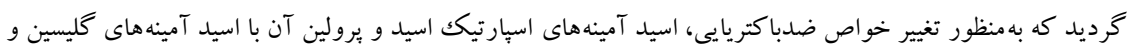
سرين جايخز ين شده بودند.

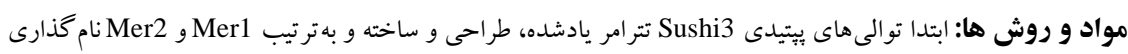

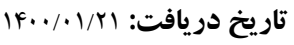

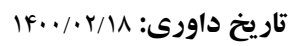

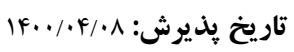

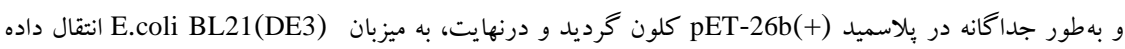

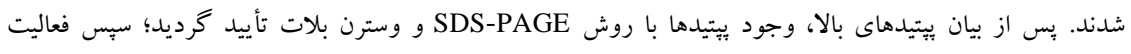

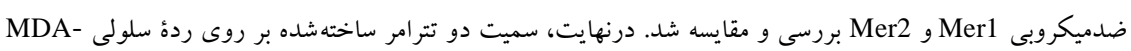
MB-231 ارزيابى و مقايسه گر ديد. يافتهها: Mer1 و Mer2 بيان بروتئينى مشابه داشتند و اثر سمى هر دو يتيتيد روى رده سلولى تفاوت معنادارى نداشت؛ اما Mer2

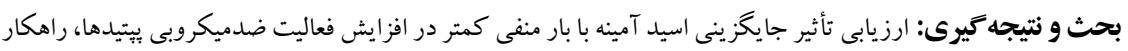

نويسنده مسئول: شاهين حدادايان كروه نانو بيوتكنولوزى، كراديان تحقيقات فناورى هاى نوين، انستيتو باستور ايران، تهران، ايران

Email:

hadadian@yahoo.com

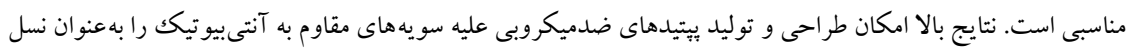
بعدى آنتى بيوتيككها افزايش ميدهد.

وازههاى كليدى: يِيتد تترامر Sushi3، خرجنگ نعل اسبى، فاكتور c، يتيدهاى ضدميكروبى

ه استناد: باغ بهشتى، سكينه؛ حداديان، شاهين؛ عيدى، اكرم؛ بيشكار، ليلا؛ رحيمى، حمزه. ارزيابى تأثير جايكزينى اسيد آمينهايى با بار منفى كمتر در يبتيد

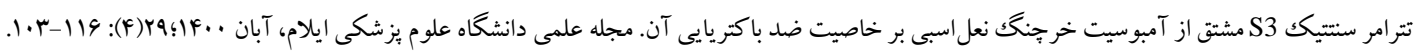


بيوتيك هاى جديد هموار سازد. يِيتيدهاى ضدميكروبى

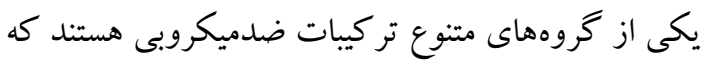

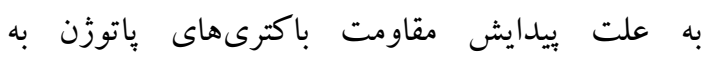
آنتى بيو تيككهاى رايج موردتوجه بسيارى قرار گرفتهاند.

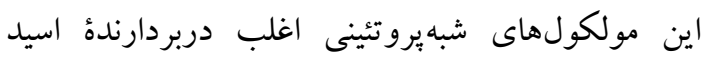

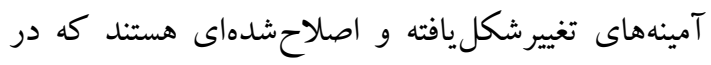

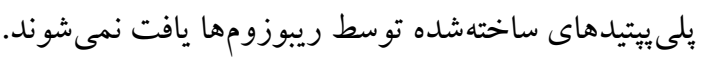

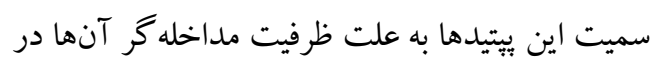
غشاى ميكروبى است كه با ايجاد منافذ در غشا، سبب القاى

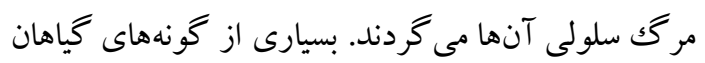

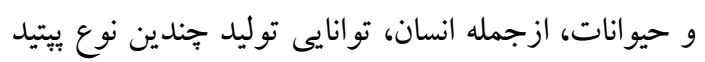

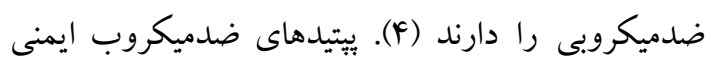

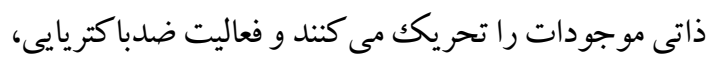
ويروسى و قارجى دارند. يبيدهاى ضدميكروبى با باسيدهاى

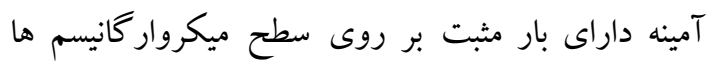

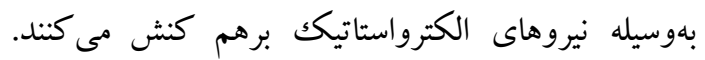

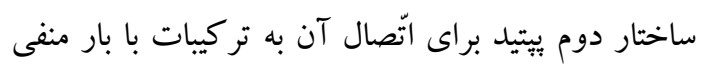
در غشاهاى هدف مانند فسفويييدهاى آنيونى، ضرورى

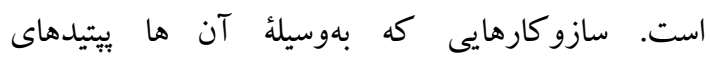
ضدميكروبى مى توانند به غشاهاى ميكروبى نفوذ كنند؛ مانند تشكيل منافذ، ترويج ساختار غيريييدى يا تخريب توني

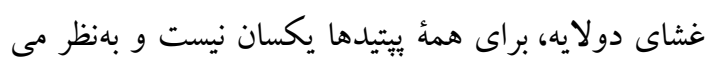
رسد كه به ويز گى هاى مولكولى ييتيد و تركيب ليييدى

$$
\text { غشاى هدف بستخى دارد (ه). }
$$

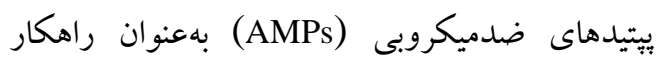

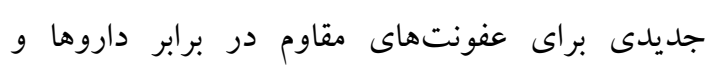

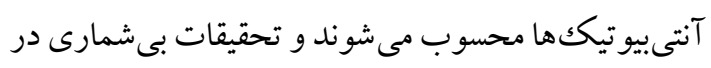

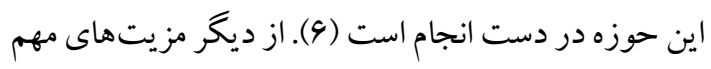
برخى از ييتيدهاى ضدميكروبى كاربرد آنها در كنترل

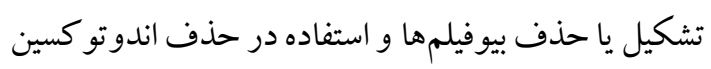

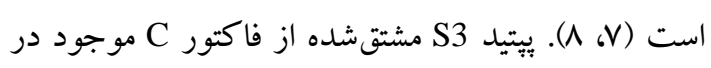

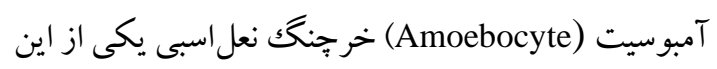
يتيدهاى ضدميكروبى است كه تحقيقات متعددى دربارة

\section{مقدمه}

افزايش عفونتهاى ناشى از باكترىهاى گرم منفى

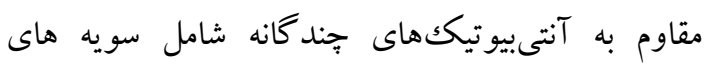
مقاوم Elebsiella pneumoniae ، Escherichia coli Pseudomonas aeruginosa carbapenem امروزه، به يكى از مهم ترين جالشهاى حوزهُ درمان تبديل شده است و درنتيجه، توليد نسل جديدى از تركيبات

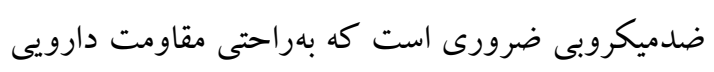

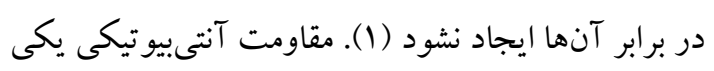
از مهم ترين معضلات بهداشتى جامعه امروز است. ايران يكى از كشورهايى است كه با تجويز بيشازاندازه آنتىبيو تيكك روبروست و مصرف آن در اين كشور، تقريباً

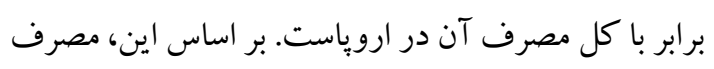

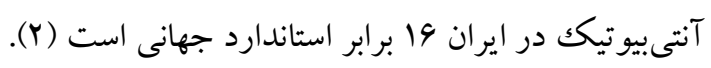
تعداد بسيارى از آنتى بيوتيكك هاى سنتزى با ساختارهاى شيميايى متفاوت، براى كنترل عفونت هاى بيمارستانى و

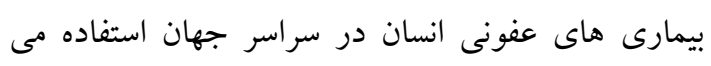

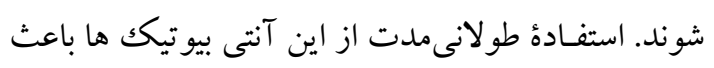
ظهور مقاومت هاى جنددارويى و باكترى هاى مقاوم مى گردد و از سويى، با آثار جانبى باعث بروز مشكلات

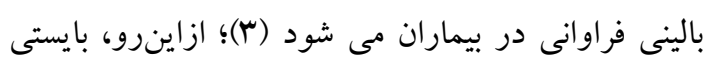

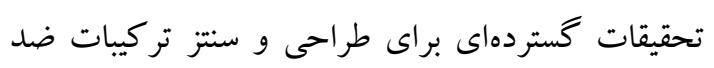
ميكروبى و يا كثف مواد ضدميكروبى جديد از منابع

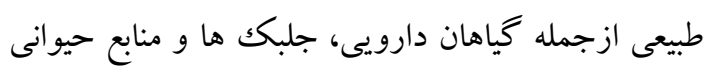

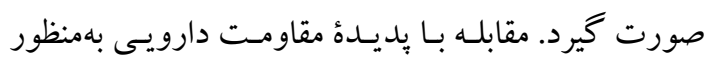
كاهش بروز آن و يا محدود كردن عوامل ميكروبى مقاوم

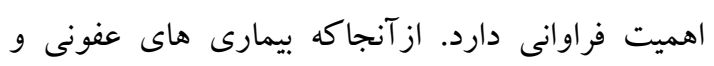

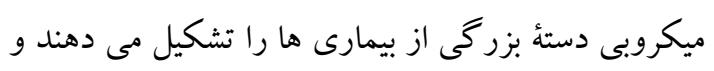

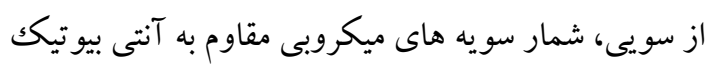

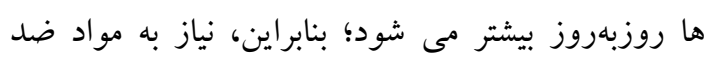

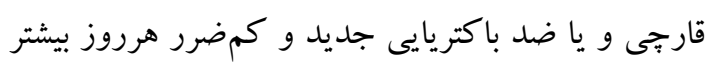
نمايان مى گردد؛ ازاينرو، بررسى آثار يتيتيدهاى سنتيك

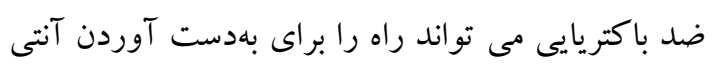


طراحىشده از ترجمه معكوس سايت ExPASy استفاده شد. سايتهاى برشى NdeI و XhoI به انتهاى 'S '5 '5 آن و

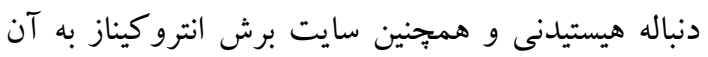

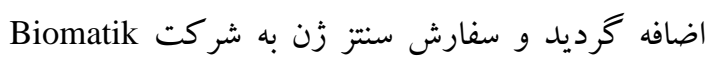

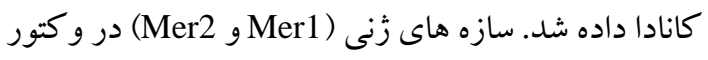
pET-26b(+)

ساختار توالى يروتئينهاى Mer1 و Mer2 (نحوه

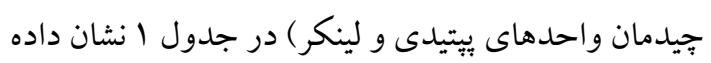

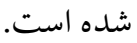

تكثير قِلاسميد، تخليص و تهيئ سلولهاى مستعل: از باكترى E. coli TOP10F بهنظور تكثير بلاسميدهاى E. مدنظر استفاده شد. يس از انتقال و كتورها به ميزبان rColi TOP10F كيت تخليص بلاسميد Qiagen صورت گرفت و نمونه ها براى مشاهدة كيفيت عمل استخراج، بر روى زل بل آكارز \% برده شدند.

E. Coli ابتدا • ا ميكروليتر از استو كك ميزبان باكتريايى لهني سوية (BL21(DE3 موجود در فريزر منفى •V درجه، بر روى بليت آكار (LB) داده و به مدت يككشب در دماى FV د درجه سانتى گراد

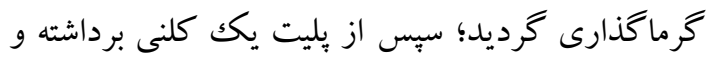
در ه ميلى ليتر از محيط كشت Luria broth (LB) تلقيح شد و در شيكر انكوباتور با دماى مV درجهُ سانتى گر اد و

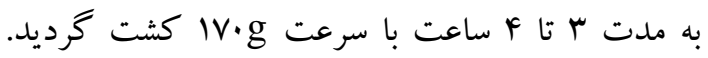
هنگامى كه جذب نورى سلولها در طولموج ل.9 نانومتر به ه/ • (فاز لكاريتمى) رسيد، سلول ها به كمكك سانتريفوز

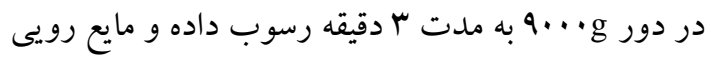
دور ريخته شد. رسوب سلولى حاصل در ..9 ميكروليتر محلول / • مولار از كلسيم كلرايد (

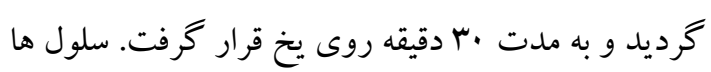

سازو كار ضدميكروبى آن صورت گرفته است. در داخل همولنف hemolymph (مايع گردشى مشابه خون) گونه

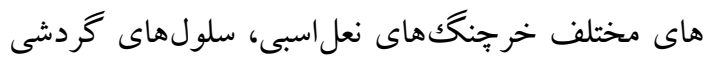

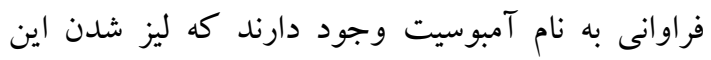

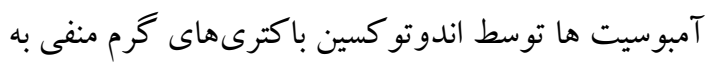
ايجاد ماده زلمانندى منجر مىشود.

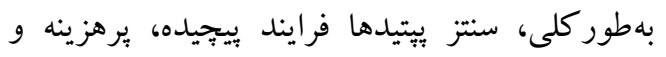

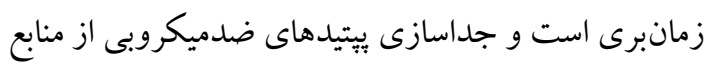

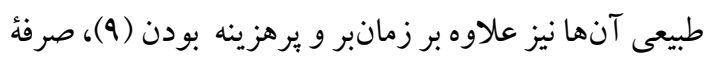
اقتصادى و زيستمحيطى ندارد. در مطالعهاى كه در سال

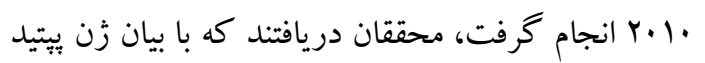
S3بهورت فرم تترامر آن، علاوه بر حفظ فعاليت

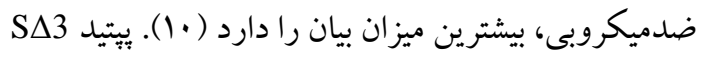

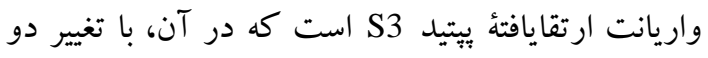

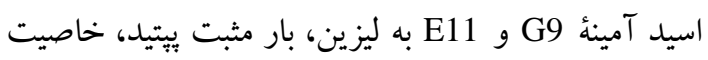
ضدميكروبى و البته اثر سميت آن افزايش يافته است. از سويى، تحقيقات نشان داده است كه فرمهاى مولتىمر ييتيد S3 نيز خاصيت ضدميكروبى دارند (1).

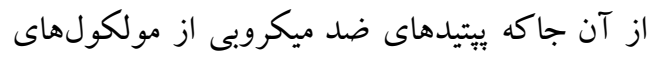
مهم ايمنى ذاتى بدن هستند و سميت سلولى اندكى دارند،

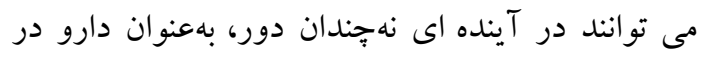

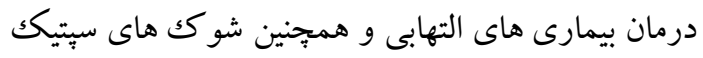

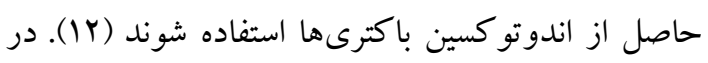
اين تحقيق، به مقايسه ميزان بيان واريانتهاى مختلف بـ بيتيد

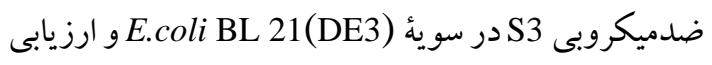
تأثير جايخزينى اسيد آمينههايى با بار منفى كمتر داراى كايلايسين، در بهبود خواص ضدميكروبى برداخته شد.

\section{مواد و روش ها}

سنتزثن: جهت تعيين توالى DNA، تو الى هاى يروتئينى

جدول 1. ساختار تو الى برو تئين هاى Mer1 و Mer2

\begin{tabular}{|c|c|c|}
\hline واحدهاى سازنده يروتئين & 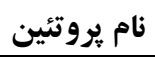 & رديف \\
\hline 10His-Entrokinase site-S3-DP-S3-DP-S3-DP-S3 & Mer1 & 1 \\
\hline 10His-Entrokinase site-S3-(GGGGS)3-S3-(GGGGS)3- S3- (GGGGS)3-S3 & Mer2 & r \\
\hline
\end{tabular}


هك ميلى ليتر رزين Ml r) NiNTA سوسيانسيون

درصد) درون ستون Hitrap يكك ميلى ليترى ريخته شد و پس از متعادلسازى با هـ ميلى ليتر بافر متعادلسازى با

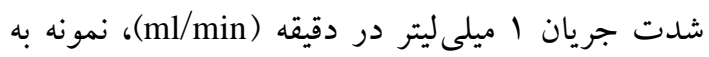

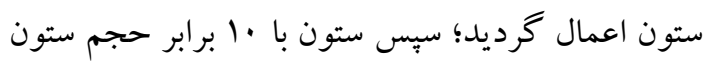

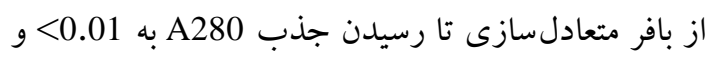

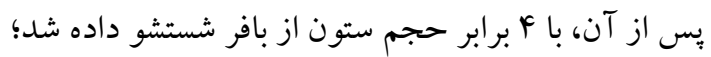

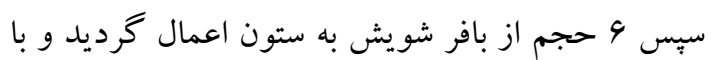

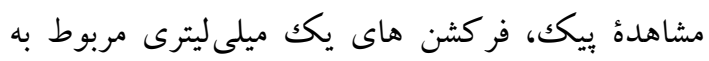

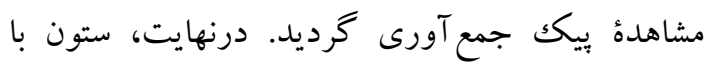
استفاده از ها حجم محلول بازيابى، براى استفاده مجدد

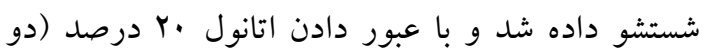

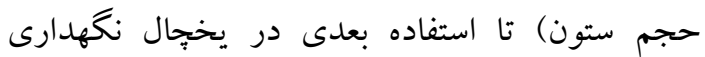

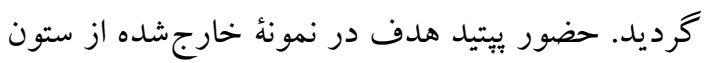
با استفاده از SDS-PAGE تأييد شد. وسترن بلاتينك (Western Blotting). بروتئين هايى

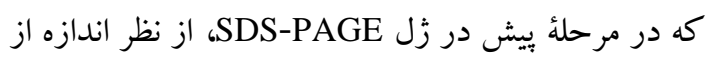

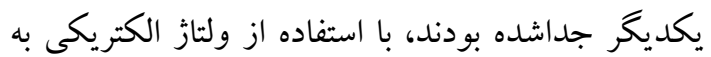
روى كاغذ نيتروسلولز منتقل گرديدند. كاغذ نيتروسلولز

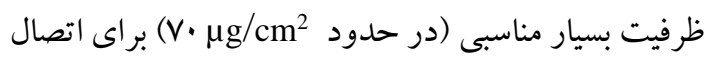

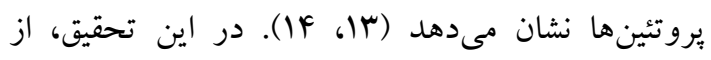

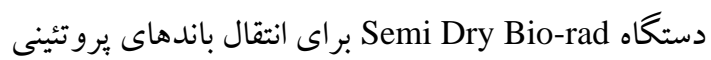
استفاده شد. براى جلو گيرى از انتقال غيراختصاصى براه

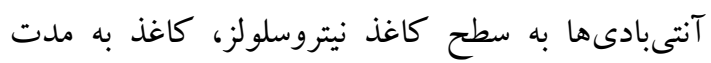
يككشب در بافر Phosphate buffered saline (PBS) حاوى Bovine Serum Albumin (BSA) هـ درصد قرار

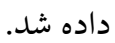

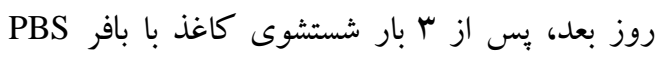

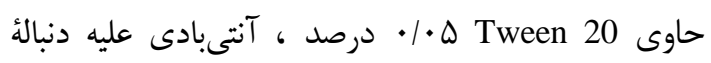

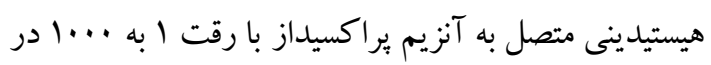

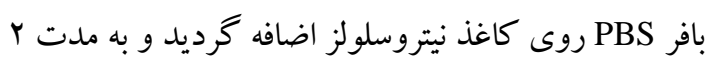
ساعت در دماى اتاق، روى شيكر قرار داده شد. بِ إس از

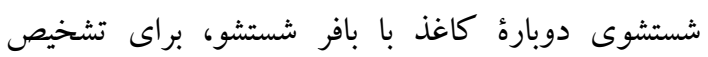

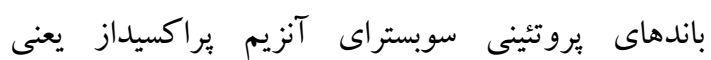

در دور g...9 به مدت س دقيقه سانتريفوز شدند. رسوب سلولى در .94ميكروليتر محلول / / • مولار از

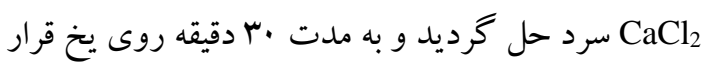
كرفت. درنهايت، سلولها دوباره در دور و

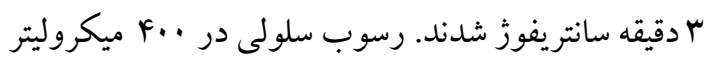
محلول / • مولار از ترانسفورماسيون باكترى BL21 با وكتور نوتركيب: بِس از آماده شدن سلولهاى مستعد، سازهُ زنى بهمنظور

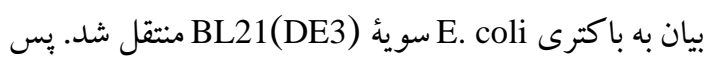

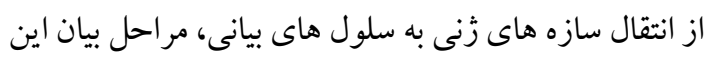

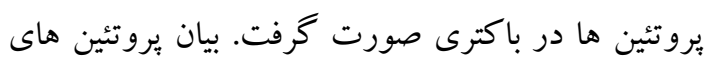

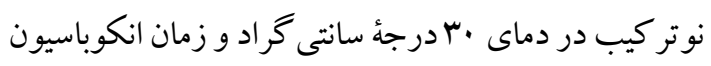

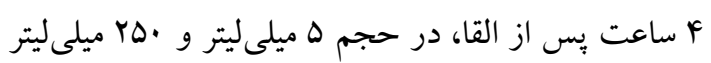
انجام گرديد.

استخراج بروتئين نوتركيب: يس إز از جداسازى زيست توده از محيط كشت بهوسيلة سانتريفيوز، ديوارهٔ

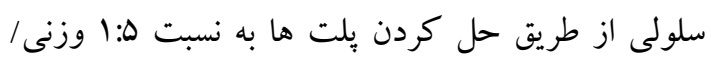
حجمى در محلول ليزكنندة

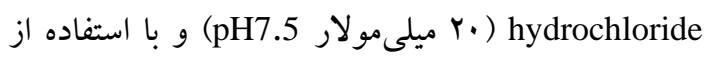

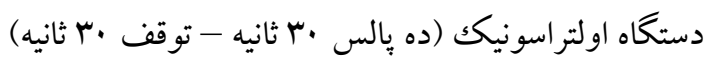
شكسته شد و بس از شستشو و حذف بقاياى ديوارهُ سلولى لئل

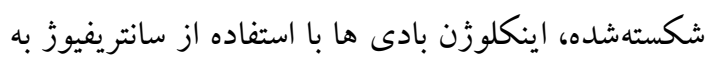

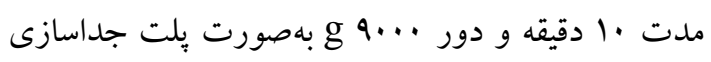

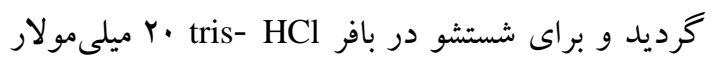
حاوى اوره Y مولار حل شد و بس از سانتر يفيوز

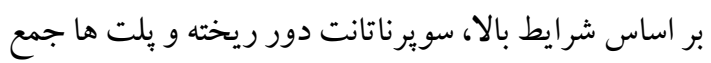

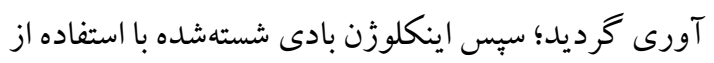

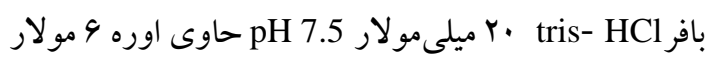

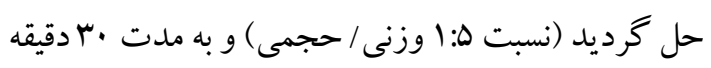
در دماى F درجه با همزن مغناطيسى همزده شد. با استفاده

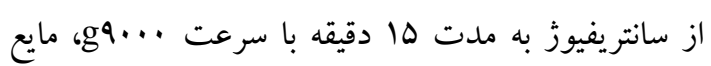
رويى حاوى بروتئين حلشده جمع آورى گرديد.

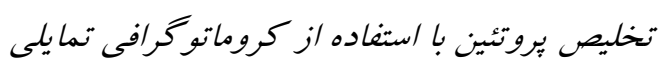
يون فلزى (IMAC). براى تخليص هريك از توالى ها، 
كرديد؛ بنابراين، جاهك هاى الى لـ ابه رقتهاى متوالى يُّيدها، جاهك هاى ستون ل/ به كنترل مثبت باكترى (رشد

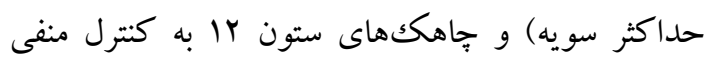
باكترى (تست سترونى آزمون) اختصاص داده شد (هاه (1).

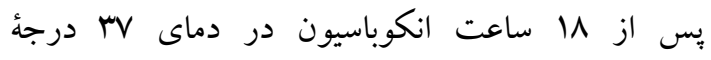

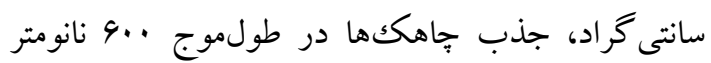
قرائت گرديد و حداقل غلظتى از يروتئين كه جذب جاب آن معادل •ه درصد جذب سلول فاقد بروتئين بود، بهعنوان

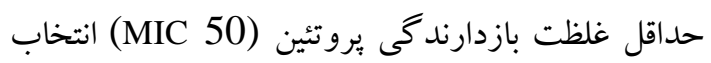

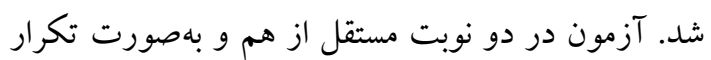
سه تايى صورت گرفت. براى تهيئ استاندارد مكك فارلند ه/ •، ابتدا محلول

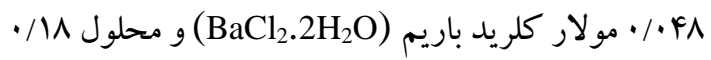

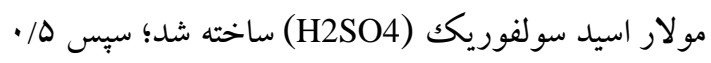

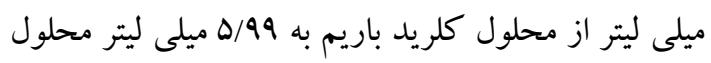

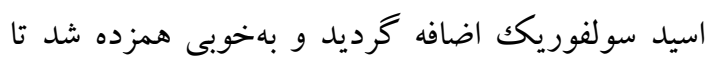

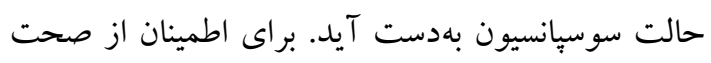
محلول سازى، جذب نورى محلول مكك فارلند

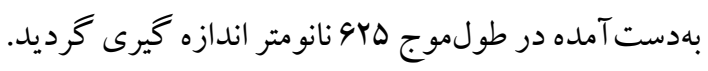
محدودة صحيح اين جذب بين ^•/• الى با// • است.

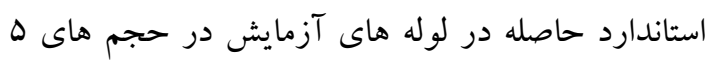

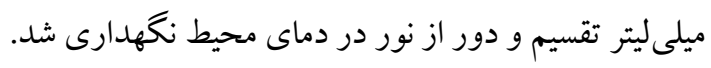

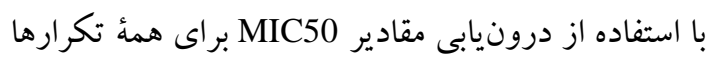

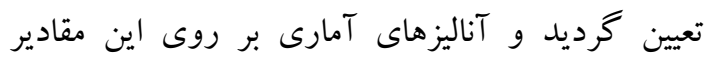

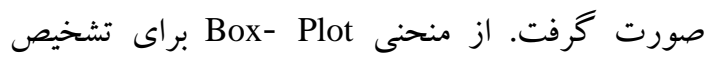
دادههاى يرت (Outlier) و از آزمون Shapiro- Wilk براى بررسى توزيع نرمال نتايج MIC50 استفاده شد. براى إن إن

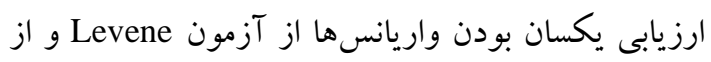
آزمون independent sample T-Test براى مقايسة MIC50 يلى يبتيدهاى موردمطالعه استفاده گرديد.

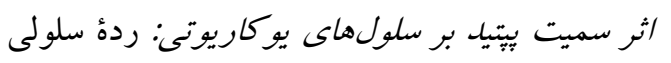
MDA-MB-231 (ATCC: HTB-26) ro انستيتو پاستور ايران تهيه و در فلاسك كشت سلولى

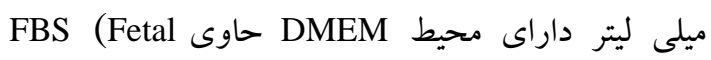

Diaminobenzidine tetrahydrochloride (DAB) r. ميكروليتر H به آن اضافه گرديد. در اثر واكنش

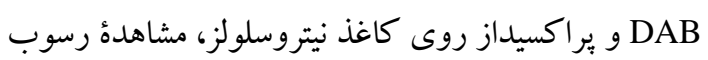
قهوهاى رنخك حضور باند يروتئين مدنظر را تأييد كرد.

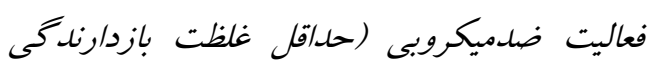
MIC50): اثر ضدميكروبى بروتئين هيبريدى حاصله، از طريق تعيين حداقل غلظت بازدارندگى مطالعه شد. براى

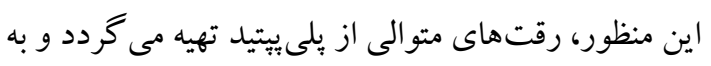
جاهك هاى يليت 99 تايى استريل افزوده مى شود. باكترى هاى گرم منفى مختلف pseudomonas aeruginosa

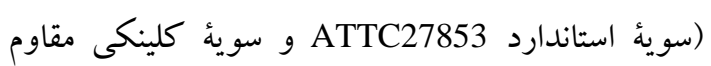
ايزولهشده در كلينيك طوس) و Escherichia coli (سوية استاندارد ATCC25922 و سوئُ كلينيكى مقاوم) ابتدا در محيط كشت Mueller Hinton كشت شبانه داده شد و سبس با افزودن · ․ ميكروليتر از كشت شبانه به ه ميلىليتر محيط تازه تا رسيدن به فاز لخاريتمى (OD 600nm 0.6) كشت گرديد؛ سيس با استفاده از سرم نمكى سترون تا بـا

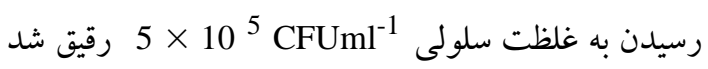
(حصول كدورت مشابه كدورت استاندارد مكك فارلند ه/·). در شرايط سترون، ميزان •ه ميكروليتر محيط كشت

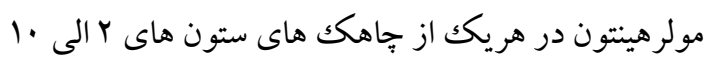

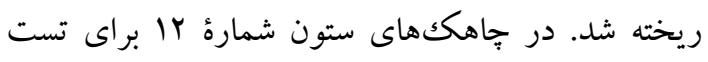
سترونى شرايط آزمون، تنها ...1 ميكروليتر محيط كشت

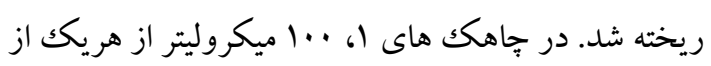
بروتئين هاى توالىهاى زن Mer1 Meq1) و زن

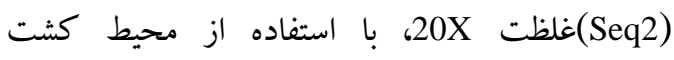
مولرهينتون · ا برابر رقيق گرديد (غلظت نهايى 2X)؛ سبس

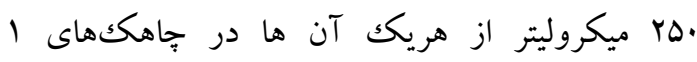
رديف هاى مربوطه ريخته شد. با كمكك سميلر جند كاناله،

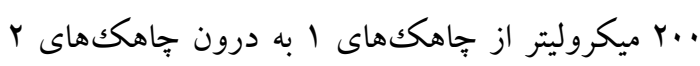

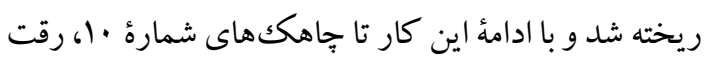

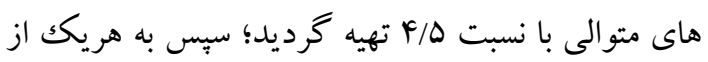

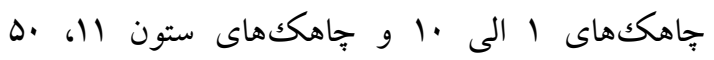
ميكروليتر از سوسيانسيونهاى ميكروبى تهيهشده اضافه 
درصد سلولها زنده بودند، بهعنوان غلظت IC50 گز ارش

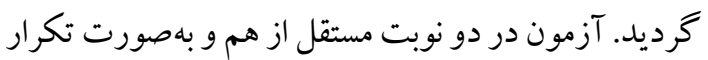
سهتيى صورت گرفت. از منحنى Box- Plot براى Shapiro- تشخيص داده هاى برت (Outlier) و از آزمون براى بررسى توزيع نرمال نتايج درصد بقاى سلولى دilk

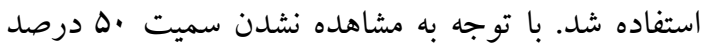
(IC50) مرجع، نتايج بقاى سلولى در بيشترين غلظت يلى ييتيد

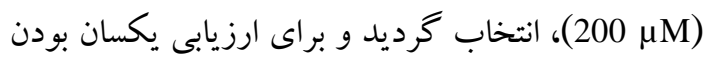
واريانسها از آزمون او بر ایى مقايسٔ ميزان سميت

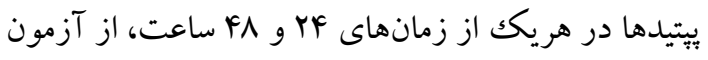
post -hoc و و آزمون LSDe way ANOVA شرايط برابرى واريانسها) و آزمون Games-Howell (در شرايط واريانسهاى نامساوى) استفاده شد. براى مقايسٔ سميت هر يتيد در زمان هاى FF و M ماعت، از آزمون independent sample T- Test

يافته ها

وسترن بلات براى تأ ييد بيان بروتئين هدف: با توجه به اينكه در سكانس هاى :يروتئين هاى مدنظر، دنباله هيستيدينى تعبيه شده بود، آزمون وسترن بلات با استفاده از آنتى بادى عليه دنبالة هيستيدينى انجام شد (شكل (1). تطابق باندهاى مشاهده شده پِ از مر حلة القاى باكترى با باندهاى

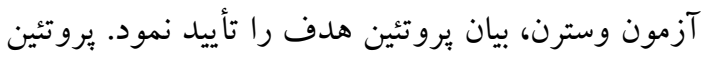
در كلونهاى متفاوت بصورت تكك باند و دو باند

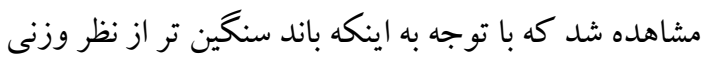

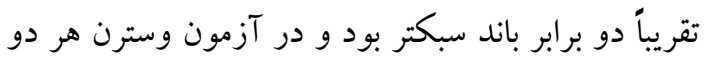
باند داراى دنباله هيسيتيدينى بودند. همجِينين باند سنگينتر

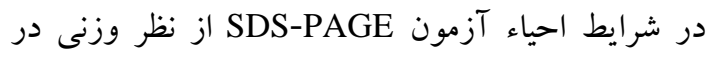
جايگاه باند اول قرار گرفت. به نظر ميرسد در كلونهاى آنس

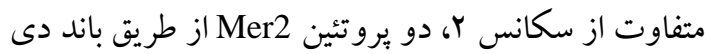
سولفيدى به صورت دايمر تبديل شده و در نتيجه در شرايط غير احياء و در آزمون وسترن در جايگاه باند سنكين تر قرار

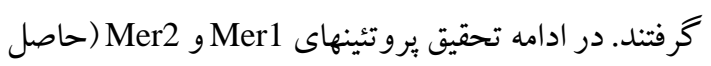

100 pg. ( حاوى آنتى بيو تيك bovine serum) 10\%

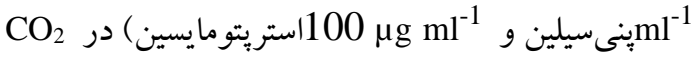

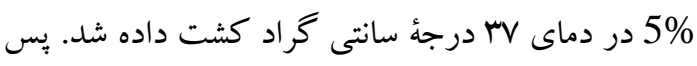

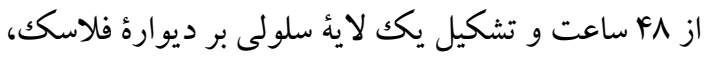

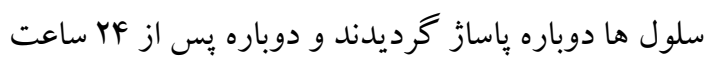
و تشكيل تكك لائٔ سلول ها، بهوسيلة تيمار ملايم با ترييسين از ديواره كنده شد و با سانتريفيوز در دماى F درجة

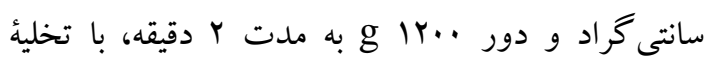

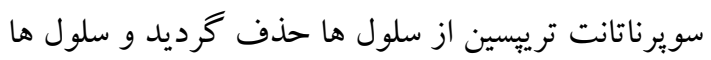
دوباره در محيط كشت بالا حل شد و يس از اطمينان از سلول ها از طريق رنخكآميزى با ترييان بلو و و

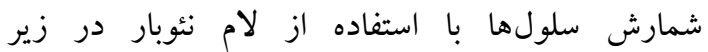

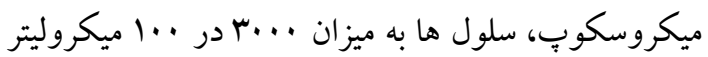
در هر קاهك ميكرويليت (99 جاهكه تخت مخصوص

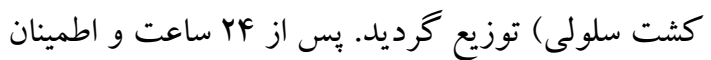

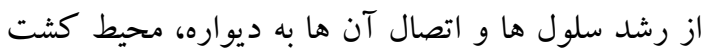
داخل جاهك ها از طريق مكث تخليه شد و غلظت هاى إن إنال مختلف هريك از يلى يِيتيدهاى ضدميكروبى (رقتهاى متوالى با نسبت يككدوم رقيقشده در محيط كشت آماده مطابق فوق) به ميزان ... ميكروليتر به هر جاهك اضافه

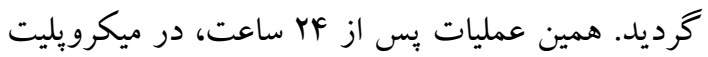

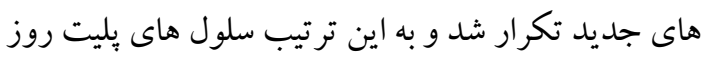
اول به مدت مA ساعت و سلول هاى يليت روز دوم به مدت FF ساعت با يلى ييتيدهاى ضد ميكروبى در تماس قرار

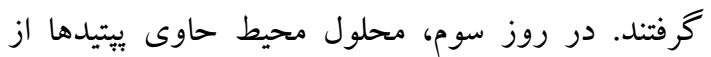

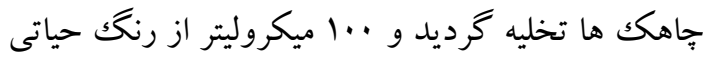

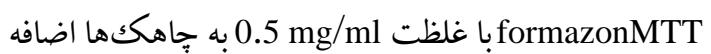
شد و بِ از F ساعت انكوباسيون در دماى rV درجه و و

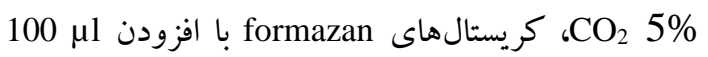
DMSO بهصورت محلول درآمده و ميزان جذب نورى

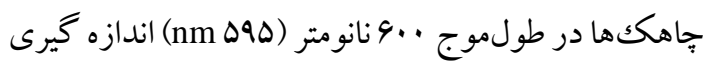

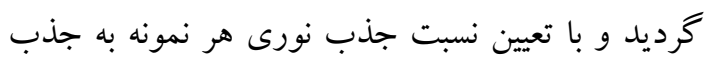

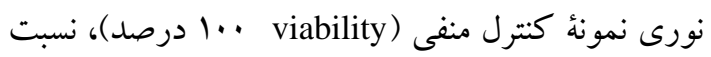

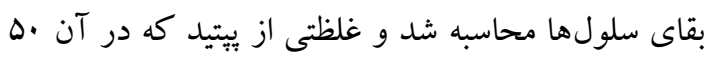


ro. نتايج درصد بقاى سلولى بعد از تماس با غلظت

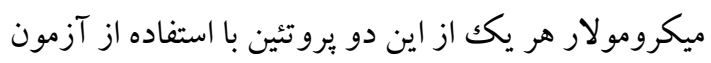
Tآمارى Independent T- test با يكديخر مقايسه شد. نتايج مربوطه در جدول شماره ب آورده شده است. در مرحله اول

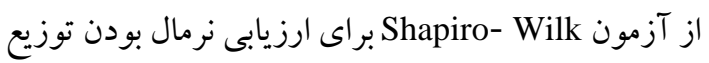

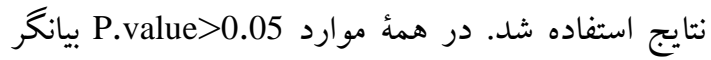

$$
\text { توزيع نرمال نتايج بود. }
$$

ميان نتايج ميزان سميت هريكك از P value> 0.05

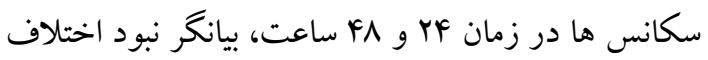

$$
\text { معنا دار در سميت سكانس ها است. }
$$

براى مقايسٔ اثر زمان بر ميزان بقاى سلولى، براى

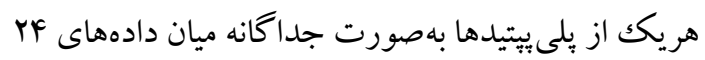

از كلون تكك باند) تخليص گرديده و براى آزمونهاى مختلف مورد استفاده قرار گر فتند.

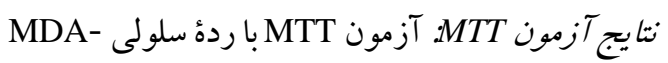

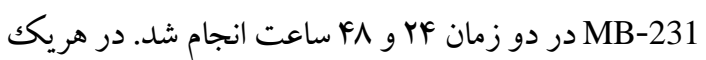

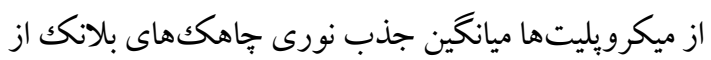
جذب نورى هريك از جاهككها كسر گرديد. در هر بليت،

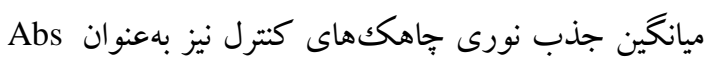

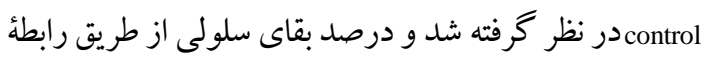
زير محاسبه گرديد:

$\%$ Cell Survival $=\left(\right.$ Abs $_{\text {sample }}-$ Abs blank $) /($ Abs control - Abs blank)*100

براى مقايسه سمّيت سلولى بروتئينهاى Mer1 و Mer2،

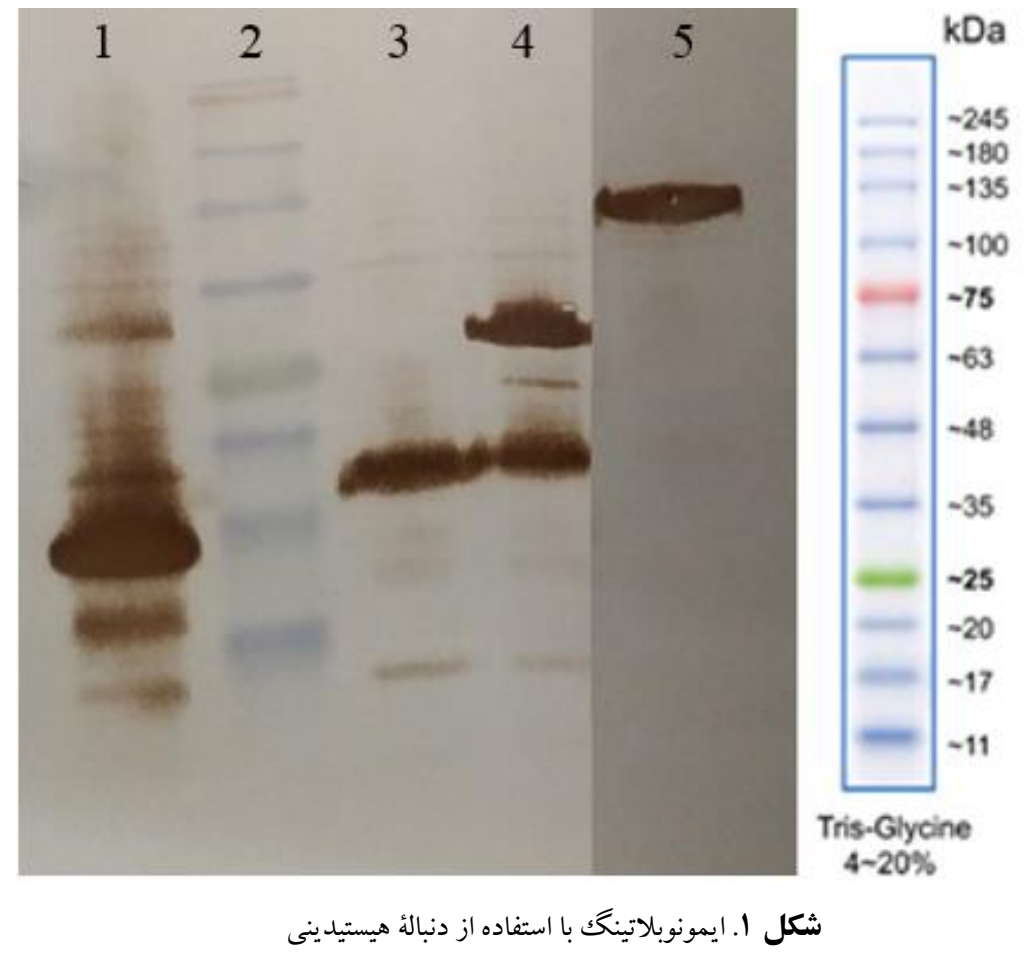

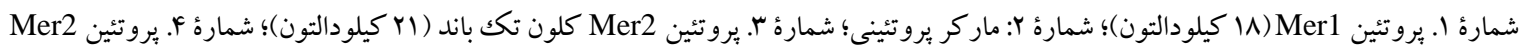

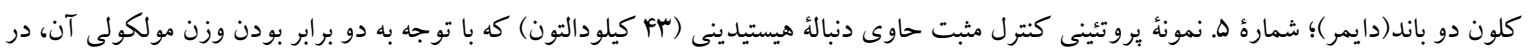

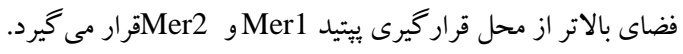

جدول r. مقايسٔ درصد بهبود خاصيت ضدميكروبى يبتيد سكانس r به نسبت سكانس ا.

\begin{tabular}{lccccc}
\hline peptide 1 & peptide 2 & $\begin{array}{c}\text { E.coli - } \\
\text { ATCC25922 }\end{array}$ & $\begin{array}{c}\text { resistant E. } \\
\text { coli }\end{array}$ & $\begin{array}{c}\text { P. aeruginosa } \\
\text { ATCC27853 }\end{array}$ & $\begin{array}{c}\text { resistant } \boldsymbol{P} \text {. } \\
\text { aeruginos } \boldsymbol{a}\end{array}$ \\
\hline Mer1 & Mer2 & 18.94 & 14.76 & 12.13 & 18.33 \\
\hline
\end{tabular}




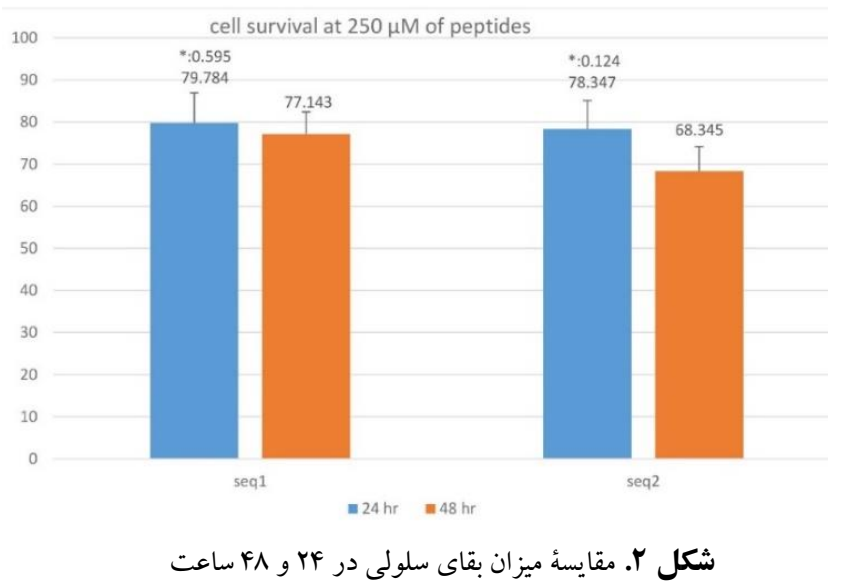

Growth Inhibition $(\%)=(\mathrm{OD}$ maximum growth -OD sample)/ OD maximum growth *100 منحنى بازدارندگى برحسب غلظت بلى ييتيد رسم

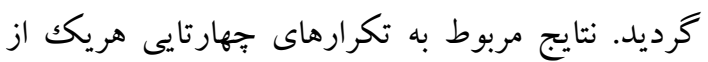
يلى يتيتيدها براى هريكك از باكترىهاى يادشده در شكل

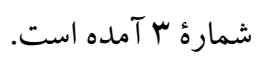

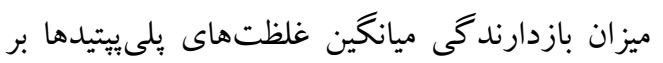

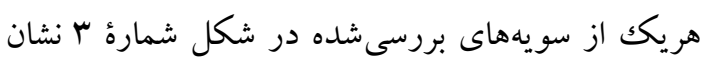

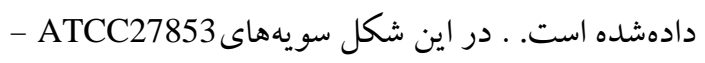
E. coli - ATCC25922، Pseudomonas aeruginosa سويههاى كلينيكى مقاوم هر يكك به ترتيب با PS-ATCC، E-res ،E-ATCC و PS-res در شكل شماره سا، با توجه به ميانگين نتايج و با استفاده

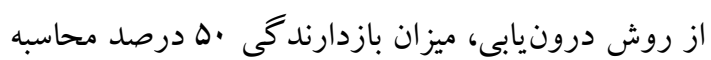

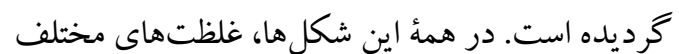

Independent T- test(16) و

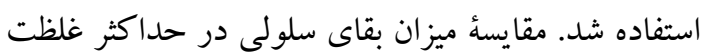

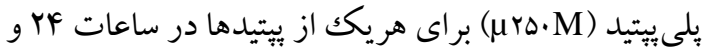
M Y ساعت، در شكل شماره Y نشان دادهشده است.

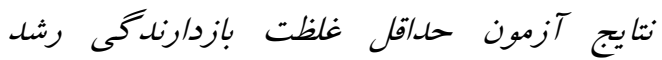
باكتريايى (MIC). تأثير غلظتهاى مختلف هريك ازد ازيج

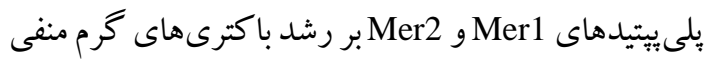
مختلف Pseudomonas aeruginosa (سوئ استاندارد E. و سوية كلينكى مقاوم ايزولهشده) و ATCC27853 coli

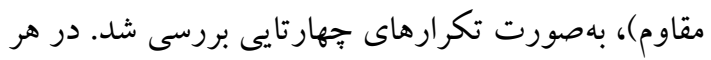

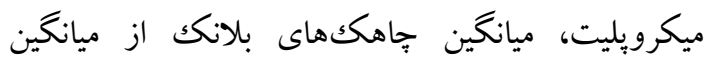
جاهك هاى حداكثر رشد كسر گرديد و ميزان بازدارندگى مانى بر اساس رابطه زير محاسبه شد:

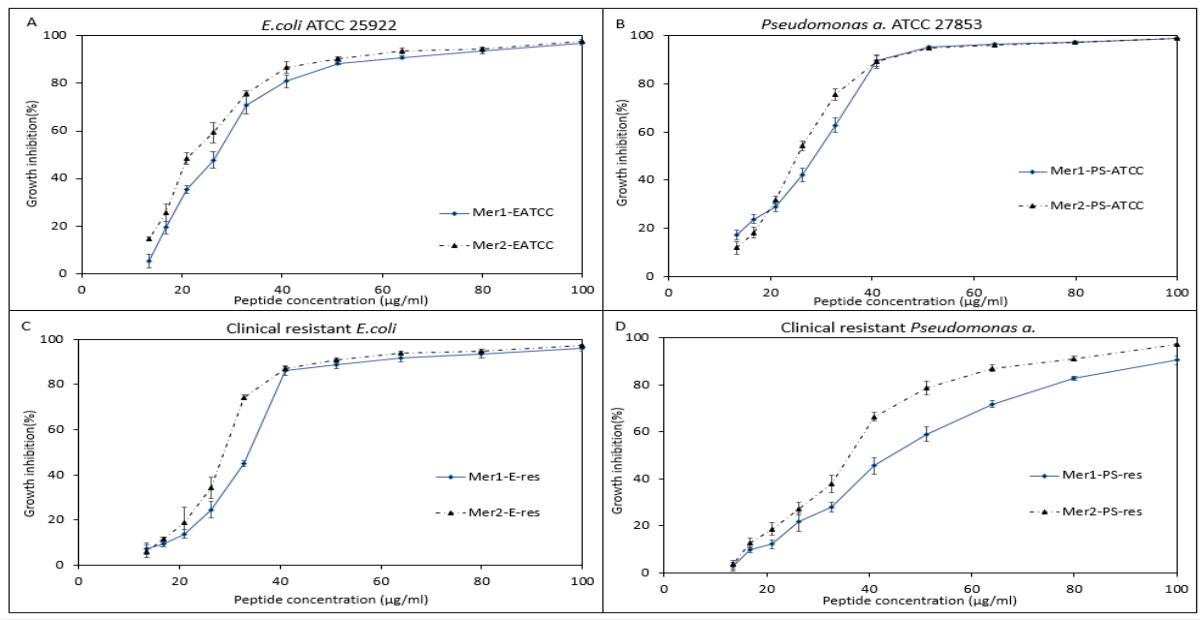

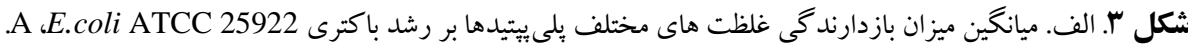

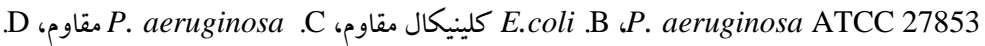




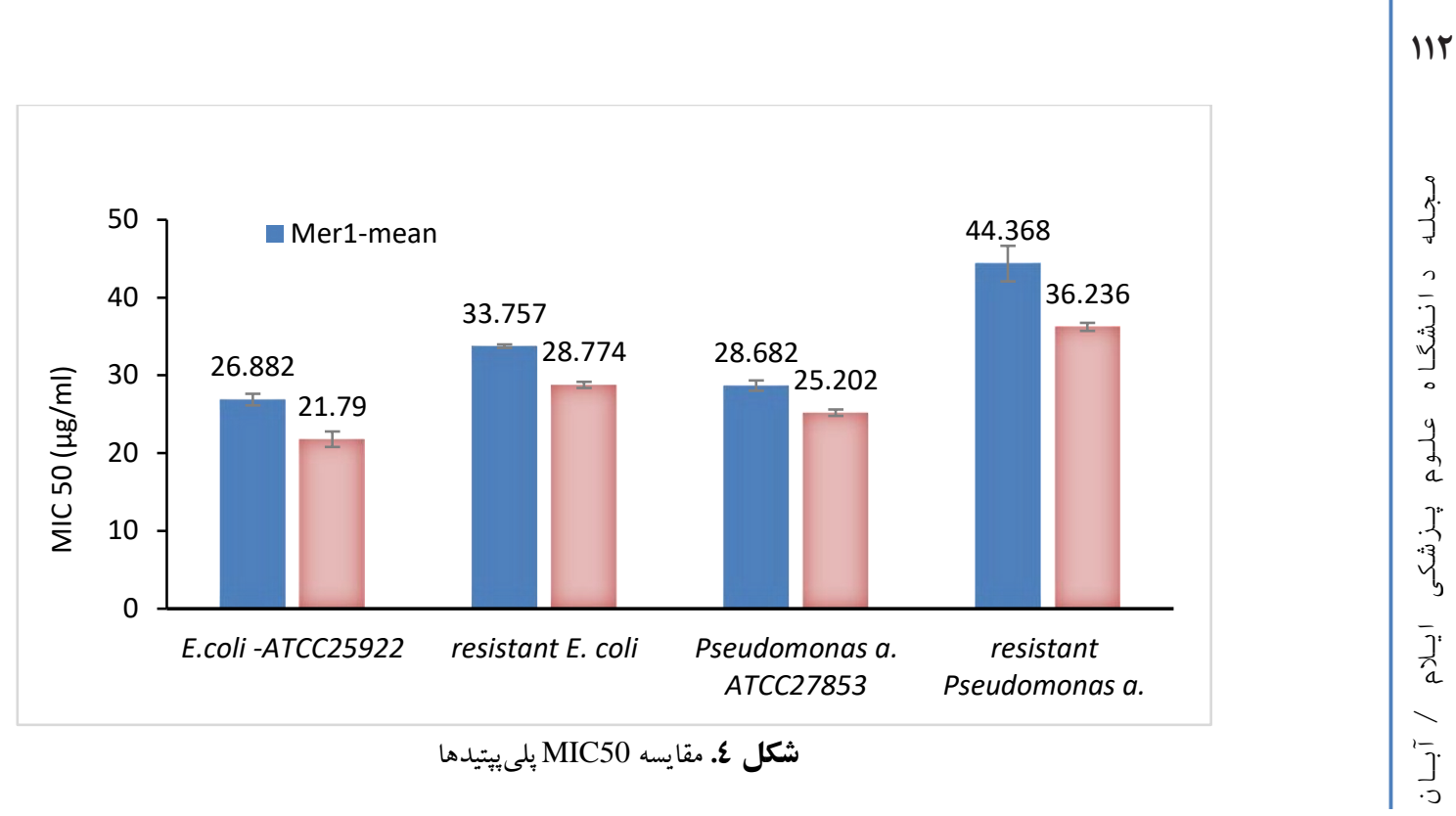

درنتيجه، همه دادهها قابلقبول و قابلمقايسه بودند. براى مقايسة MIC هريك از توالى ها روى هريك از سويه ها، از آزمون Independent T test استفاده شد. در همء موارد P value>0.05 بود كه بيانگر معنادار بودن اختلافات مشاهدهشده ميان نتايج بود؛ بنابراين، براى بررسى ميزان بهبود خاصيت ميكروبى از حالت كاهش غلظت MIC بر اساس رابطة زير استفاده گرديد و نتايج در جدول شمارهء نشان داده شد.

MIC improvement $=($ MIC 50 peptide 1-( MIC 50 peptide 2) / MIC 50 peptide $1 * 100$

بر اساس نتايج جدول شماره س، استفاده از اسيد

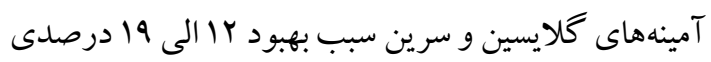
حداقل غلظت بازدارندگى رشد ميكروبى در سويههاى مطالعهشده گرديد.

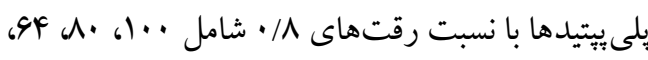

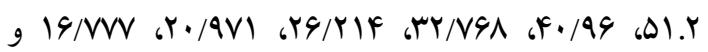
Mg/ml Ir/FYY تهيه شدهاند. براى سهولت مقايسه، اطلاعات MIC بg/ml 50 در شكل شماره دوباره نمايش دادهشده است. براى بررسى معنادار بودن اختلافات مشاهدهشده در شكل شمارهُ F، مقادير MIC50 براى هريك از تكرارها با استفاده از درونيابى تعيين گرديد و نتايج از نظر آمارى آناليز شد. در آزمون Shapiro- Wilk، بودن توزيع همهُ تكرارهاى MIC50 بود؛ بنابراين، براى مقايسٔ آنها از آزمون پِارامترى ANOVA استفاده شد. از نمودار BOX plot براى تشخيص داده هاى يرت استفاده شد و داده يرتى وجود نداشت و (outlier)

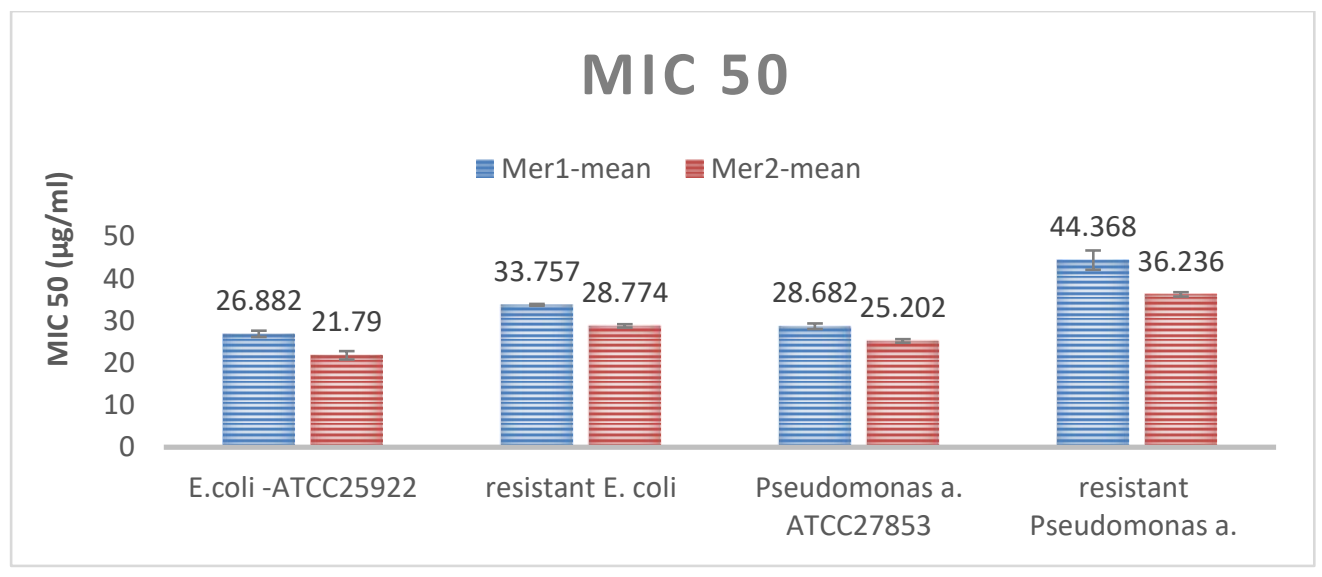

شكل 0. مقايسه MIC50 يلى ييتيدها 
جدول r. مقايسٔ درصد به.بود خاصيت ضدميكروبى يتيد سكانس Y به نسبت سكانس I

\begin{tabular}{lccccc}
\hline peptide 1 & peptide 2 & $\begin{array}{c}\text { E.coli - } \\
\text { ATCC25922 }\end{array}$ & $\begin{array}{c}\text { resistant E. } \\
\text { coli }\end{array}$ & $\begin{array}{c}\text { P. aeruginosa } \\
\text { ATCC27853 }\end{array}$ & $\begin{array}{c}\text { resistant } \boldsymbol{P} \text {. } \\
\text { aeruginosa }\end{array}$ \\
\hline Mer1 & Mer2 & 18.94 & 14.76 & 12.13 & 18.33 \\
\hline
\end{tabular}

محاسبه گرديد كه نشاندهنده بهبود حدود هr درصدى بحث و نتيجه كيرى

خاصيت ضدميكروبى Mer2 نسبت به Mer1 است.

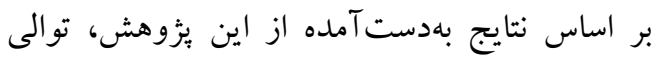

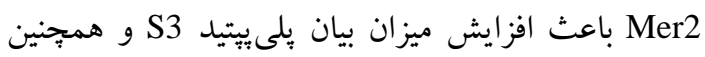
افزايش خاصيت ضدميكروبى آن شد. بهطور مشابه، اثر اين

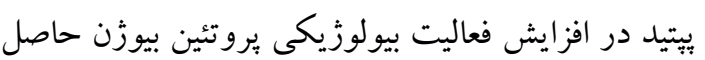

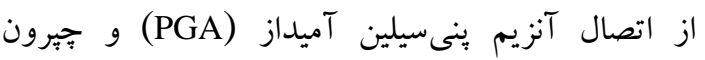
مشتقشده از (rTHS) Methanocaldococcus jannschii گزارش گرديده است. تأثير مثبت Mer2 در افزايش بايدارى و تصحيح تاخورد گَى در برخى از مطالعات بيان

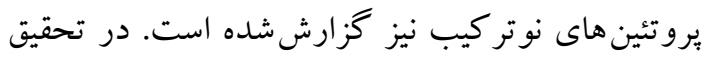

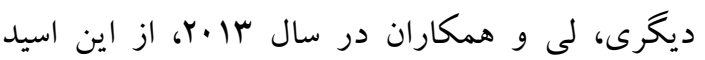

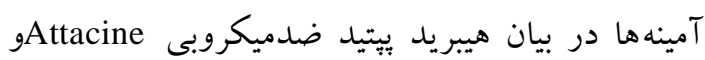
Coleoptericin خاصيت ضدميكروبى يُيتيد هيبريد بهدست آمده در مقايسه با هريك از يّتيدهاى ضدميكروبى بهصورت

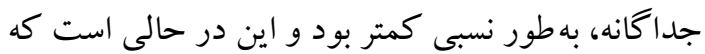

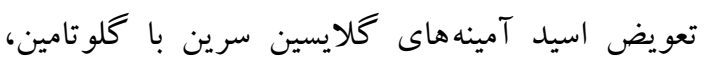
آلانين و ليزين سبب بهبود خاصيت ضدميكروبى هيبريد

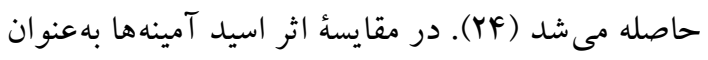

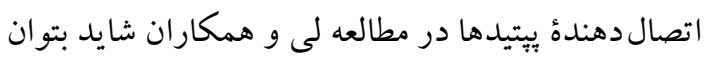
بهبود خاصيت ضدميكروبى در جايكزين كردن كلو تامين، آلانين و ليزين به افزايش بار مثبت يبتيد در اثر بردئ حضور اسيد آمينة ليزين در اين يبتيد نسبت داد. بهطور

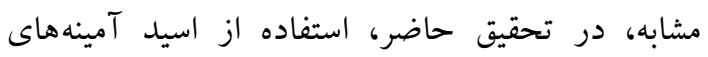

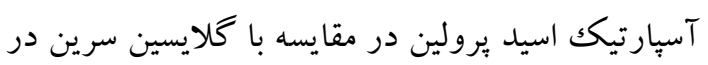

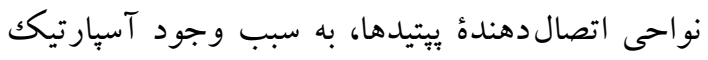

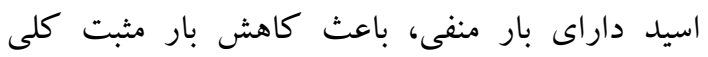
يروتئين از +9 به +9 مى شود؛ بنابراين، به نظر مىرسد

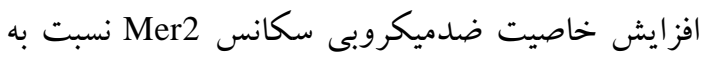
سكانس Mer1 مى تواند با حضور ب بار مثبت بيشتر و

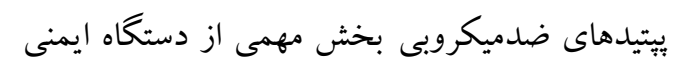

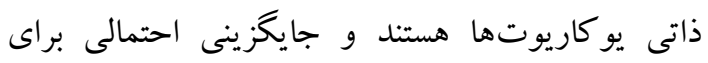
آنتىبيوتيككهاى رايج ارائه مىدهند؛ بنابراين، دركا هـ

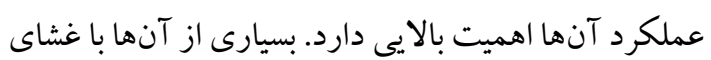

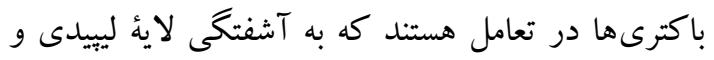

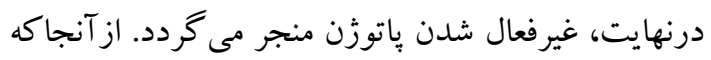
به علت تجويز بيشازحد آنتىبيوتيكها، باكترىهاى

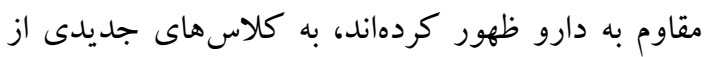

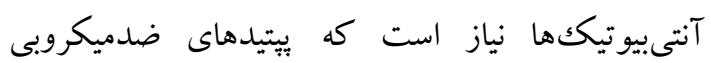
مى تواند يكى از اين جايكزين هاى ارزشمند باشد. نئ.

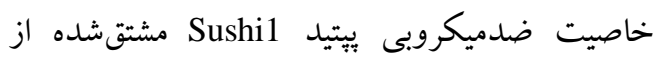

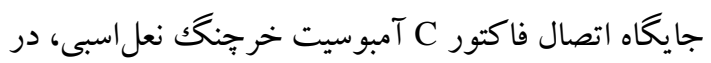
مطالعهاى بهوسيلة روش ليز باكترىهاى گرم منفى زندأ فلورسنت به اثبات رسيده است. در اين روش، با استفاده از Sushi1 ضدميكروبى يبتيد در سطح تككمولكولى مشاهدهده ناندان است (IV) مشتقشده از دمين Sushi3 فاكتور C به سبب خاصيت

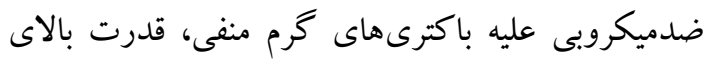

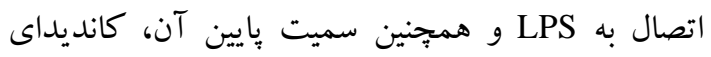

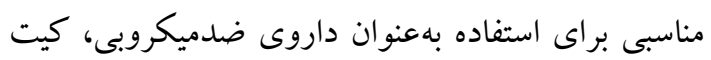

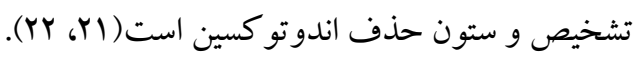

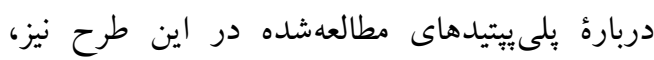
تشكيل بيوند دى سولفيدى در تريمر Mer2 از طريق مقايسٔ نتايج آزمون SDS-PAGE آنها در حالت احيا و غير احيا تأييد گرديد.

براى بررسى اثر استفاده از Mer1 در مقايسه با Mer2،

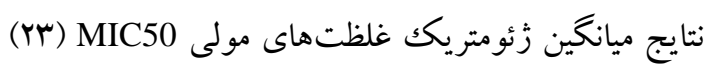
در اين دو توالى با يكديخر مقايسه شدند. 50 GM MIC

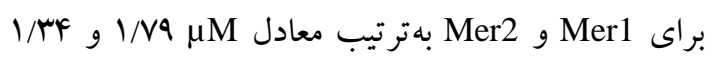


دربارهُ يِتيدهاى خطى S1 يا S3، در همدٔ مطالعات موجود از روش سنتز فاز جامد اين يُيتيدها استفاده شده و تنها گزارش توليد نوتركيب آنها، مربوط به بيه بيان

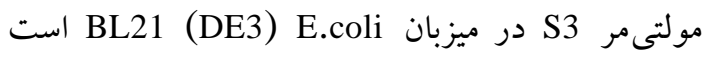

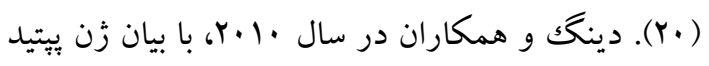

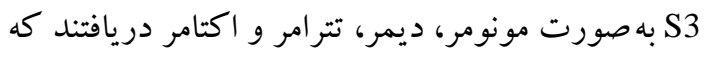

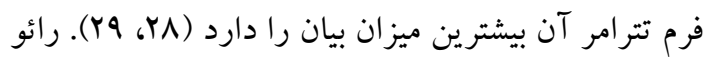

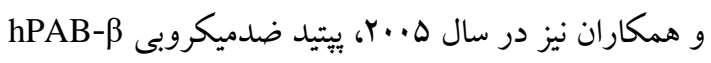
را بهصورت مولتىمر در(DE3) E.coli BL21(Dيان

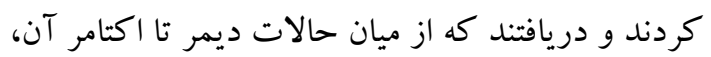
بيشترين ميزان بيان در حدود rV/A درصد مربوط به بيان زن اين يتيد بهصورت ترايمر بود (·r). در اين تحقيق،

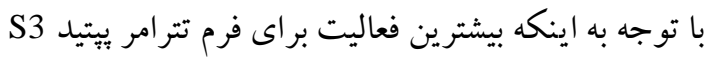

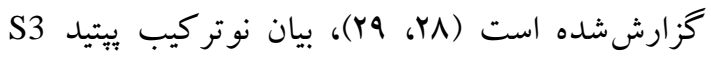
بهصورت تريمر و همجنين S3 تريمرى كه در آن اسيد

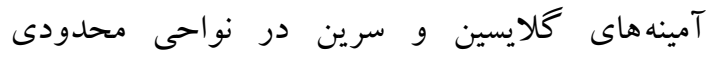

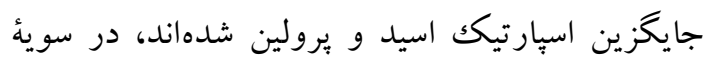

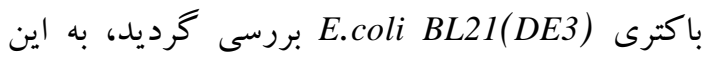
صورت كه زُن مربوط به توالى هاى مدنظر پس از سنتز و و تكثير، به باكترى E.coli BL21 منتقل شد و بس از القاى باكترى با IPTG، بيان يروتئين هاى هدف با استفاده از آزمونهاى SDS-PAGE و و وسترن (عليه دنبالة هيستيدينى) انجام و بيان آنها تأييد گرديد. در مقايسٔ ميزان بيان واريانتهاى مختلف يُّيتيد تريمر سنتيكك S3 در سوية (E.coli BL 21(DE3 و ارزيابى تأثير جايخزينى اسيد آمينهايى با بار منفى كمتر اين ييتيد در

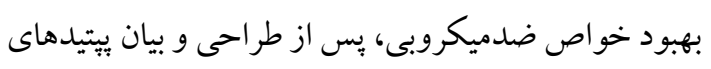

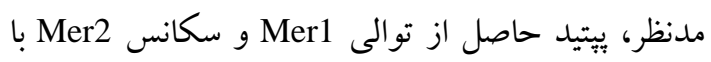

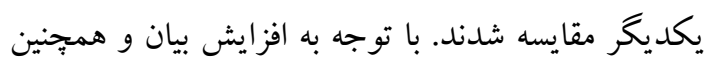

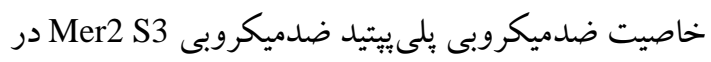

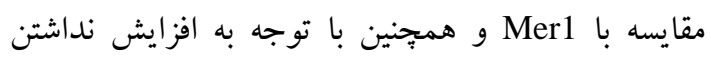

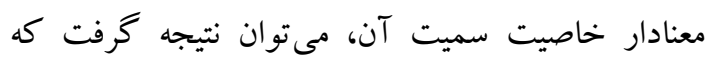
جايخز ينى اسيد آمينه با بار منفى كمتر در بيان تترامر يِتيد ضدميكروبى S3 استراتزى مناسبى است.
همجِنين افزايش محتواى كلايسينى اين يبتيد ارتباط

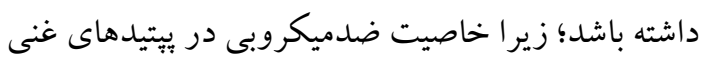

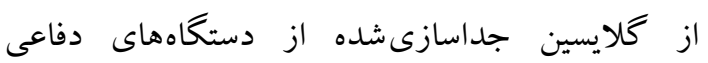
موجوداتى نظير عقرب و خرجنَّك عقربى، در مقالات مختلف گزارش شده است (YV-YO). در بيان نوتر كيب يُيتيدهاى ضدميكروبى اعم از بيان فيوزن يا مولتىمر، بررسى اثر سميت بروتئين بهدست آمده

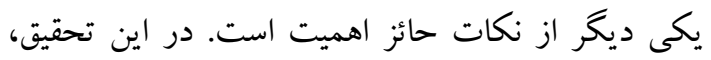

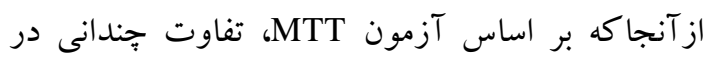

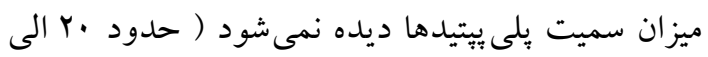

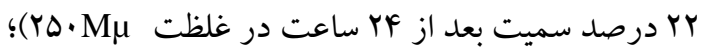

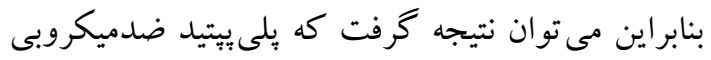
Mer2 S3

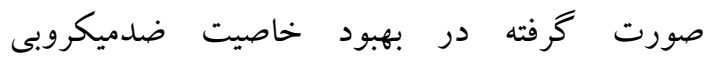
يلى يبتيدهاى طراحى شده تأثير مثبت داشته و قابل قبول است. لازم به توضيح است كه بر اساس نمودارهاى ميزان

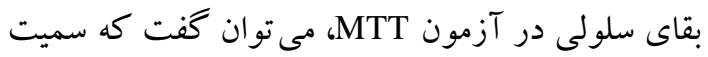
جزئى مشاهدهشده براى همة سكانس ها وابسته به غلظت و زمان است (P value >0.05)؛ اما نكتئ مهم اين است كه بيلىيبتيدها در غلظت MIC 50 اثر سميت ندارند. در

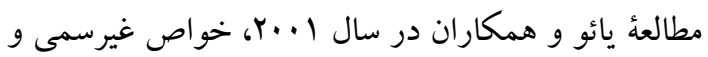

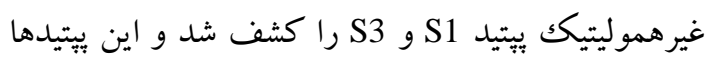
به عنوان كانديداى مناسبى در سبتيك هاى ميكروبى معرفى

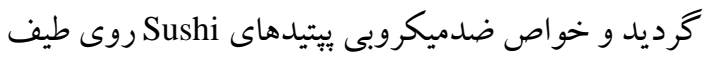
وسيعى از باكترىهاى گرم منفى بررسى شد شد (IV)

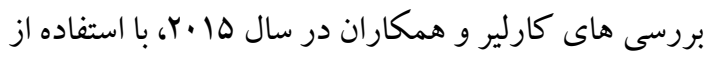

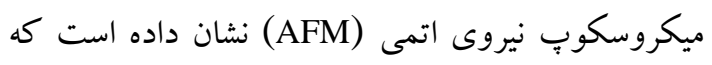
يبتيد S3 از طريق تخريب غشاى بيرونى و نفوذيذير ساختن غشاى درونى و درنهايت، از طريق تكهتكه كردن هر دو

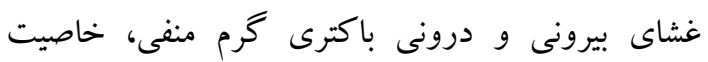
ضدميكروبى خود را بروز مى دهد. لِتين و همكاران در سال

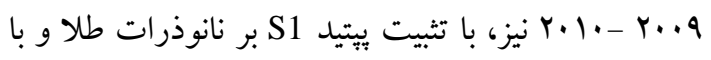

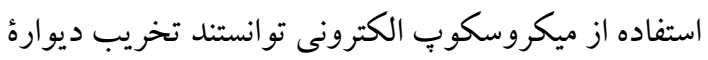

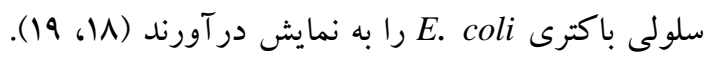




$$
\begin{aligned}
& \text { كد اخلاق } \\
& \text { اين مطالعه فاقد كار آزمايى بالينى بوده و كد اخلاق } \\
& \text { در مورد آن كاربرد نداشت. }
\end{aligned}
$$

\section{References}

1. Kaye KS, Pogue JM. Infections Caused by Resistant Gram-Negative Bacteria: Epidemiology and Management. Pharmacotherapy: The Journal of Human Pharmacology and Drug Therapy. 2015;35:949-62. doi.10.1002/phar.1636.

2. Jenkinez V, Ranjitha K. Phytochemical and antibacterial studies of chicory a multipurpose medicinal plant stress physiology and medicinal plant biotechnology unit. Sch Life Sci Bharathidasan Uni Nadu India2008;2:620 4.

3. Moniri R, Mosayebi Z, Movahedian AH, Mossavi GhA. Increasing trend of antimicrobial drugresistance in Pseudomonas aeruginosa causing septicemia. Iranian J Pub Health 2006;35:58-62.

4. Evelien Berends. Role of antimicrobial peptides in human innate defense against bacteria master program Infection and Immunity. Msc Thes Uni Med Cent Utrech Heidelberglaan2010;1-70.

5. Guilhelmell N, Vilel F. Antibiotic development challenges the various mechanisms of action of antimicrobial peptides and of bacterial resistance. Front Microbiol2013; 4:353. doi. 10.3389/fmicb.2013.00353.

6. Engler AC, Wiradharma N, Ong ZY, Coady DJ, Hedrick JL, Yang YY. Emerging trends in macromolecular antimicrobials to fight multi drug resistant infections. Nan Tod2012;7:201-22. doi. 10.1016/j.nantod.2012.04.003.

7. Maisetta G, Grassi L, Di Luca M, Bombardelli S, Medici C, Brancatisano FL, et al. Anti biofilm properties of the antimicrobial peptide temporin $1 \mathrm{~Tb}$ and its ability, in combination with EDTA, to eradicate Staphylococcus epidermidis biofilms on silicone catheters. Biofouling 2016;32 :787-800. doi. 10.1080/08927014.2016.1194401.

8. Mansour SC, Hancock RE. Peptide idr1018 modulating the immune system and targeting bacterial biofilms to treat antibioticresistant bacterial infections. J Pept Sci 2015;21:323-9. doi. 10.1002/psc. 2708.

9. Li Y. Recombinant production of antimicrobial peptides in Escherichia coli a review. Protein Exp Pur2011;80:260-7. doi.10.1016/j.pep.2011.08.001.

10. Ding J L, Ho B. inventors; Google Patents, assignee. Sushi peptide multimer patent. 2010;US7763704B2.

11. Leptihn S, Guo L, Frecer V, Ho B, Ding J L, Wohland T. One step at a time action mechanism of Sushi1 antimicrobial peptide and derived molecules. Virulence 2010;1:42-4. doi.10.4161/viru.1.1.10229.

12. Asoodeh A, Zardini H Z, J C. Identification and characterization of two novel antimicrobial peptides, temporin-Ra and temporin $\mathrm{Rb}$ from skin secretions of the marsh frog rana ridibunda. J Pept Sci2012; 18:10-6. doi.10.1002/psc.1409.

13. Přistoupil TI, Kramlova M, Štěrbíková J. On the mechanism of adsorption of proteins to

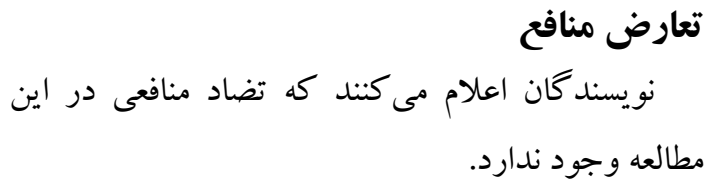

nitrocellulose in membrane chromatography. J Chromatograph1969; 42:367-75. doi.10.1016/ S0021-9673(01)80636-1.

14. Tang RH, Li M, Liu LN, Zhang SF, Alam N, You M, Ni YH, Li ZD. Chitosan modified nitrocellulose membrane for paper based point of care testing. Cellulose2020;27:3835-46. doi.10.1007/s10570020-03031-x.

15. Wiegand I, Hilpert K, Hancock RE. Agar and broth dilution methods to determine the minimal inhibitory concentration of antimicrobial substances. Nature Prot 2008 ;3:163-75. doi. 10.1038/nprot.2007.521.

16. Markossian S, Grossman A, Brimacombe K, Arkin M, Auld D, Austin CP, et al. Assay guidance manual bethesda. $1^{\text {th }}$ ed. Comp National Cent Adv Trans Sci Publication. 2004;P.33-86.

17. Ding JL, Li P, Ho B. The Sushi peptides structural characterization and mode of action against Gram negative bacteria. Cell Mol Life Sci2008;65:120219. doi.10.1007/s00018-008-7456-0.

18. Leptihn S, Guo L, Frecer V, Ho B, Ding JL, Wohland T. One step at a time: Action mechanism of Sushil antimicrobial peptide and derived molecules. Virulence2010;1:42-4. doi. 10.4161/viru.1.1.10229.

19. Leptihn S, Har JY, Chen J, Ho B, Wohland T, Ding JL. Single molecule resolution of the antimicrobial action of quantum dot labeled sushi peptide on live bacteria. BMC Biolo 2009;7:1-3. doi.10.1186/1741-7007-7-22 .

20. Li P, Sun M, Wohland T, Ho B, Ding JL. The molecular mechanism of interaction between sushi peptide and Pseudomonas endotoxin. Cell Mol Immunol2006;3:21-8.

21. Ding JL, Zhu Y, Ho B. High-performance affinity capture removal of bacterial pyrogen from solutions. J Chromatograph Biomed Sci Appl 2001;759:23746. doi.10.1016/S0378-4347(01)00227-4.

22. Ding J, Ho B, Tan N, inventors. Recombinant proteins and peptides for endotoxin biosensors endotoxin removal and anti microbial and anti endotoxin. Therapeutics2003;3:213-8.

23. Zhang SK, Song JW, Gong F, Li SB, Chang HY, Xie HM, et al. Design of an ahelical antimicrobial peptide with improved cell-selective and potent anti biofilm activity. Sci Rep 2016;6:1-3. doi.10.1038/srep27394.

24. Lee M, Bang K, Kwon H, Cho S. Enhanced antibacterial activity of an attacin-coleoptericin hybrid protein fused with a helical linker. Mole Biol Rep 2013;40:3953-60. doi.10.1007/s11033012-2472-4

25. Lorenzini DM, Silva JRPI, Fogaça AC, Bulet P, Daffre S. Acanthoscurrin a novel glycine rich antimicrobial peptide constitutively expressed in the hemocytes of the spider acanthoscurria gomesiana. Deve Comp Immunol2018 ;27:781-91. 
doi.10.1016/S0145-305X(03)00058-2.

26. Park CJ, Park CB, Hong SS, Lee HS, Lee SY, Kim SC. Characterization and cDNA cloning of two glycine and histidine-rich antimicrobial peptides from the roots of shepherd's purse Capsella bursa pastoris. Plant Mole Biol2000;44:187-97. doi:10.1023/a:1006431320677.

27. Sperstad SV, Haug T, Vasskog T, Stensvåg K. Hyastatin, a glycine-rich multi-domain antimicrobial peptide isolated from the spider crab (Hyas araneus) hemocytes. Molecular
Immunology. 2009 Aug 1;46(13):2604-12. doi: https://doi.org/10.1016/j.molimm.2009.05.002.

28. Ding JL, Ho B. Inventors assignee sushi peptides. $1^{\text {th }}$ ed. Multimer Publication. 2005;P.245-66.

29. Ding JL, Ho B, Inventors assignee sushi peptides. $3^{\text {th }}$ ed. Multimer Publication. 2010;P.133-72.

30. Rao X, Hu J, Li S, Jin X, Zhang C, Cong Y, et al. Design and expression of peptide antibiotic hPAB- $\beta$ as tandem multimers in Escherichia coli. Peptides 2005;26:721-9. doi. 10.1016/j.peptides.2004.12.016 